\title{
FUNCTIONAL OUTCOME OF COMMINUTED PROXIMAL TIBIAL FRACTURE TREATED BY LOCKING PLATE
}

\author{
Dr Harikrishna Koya Ms (Ortho) ${ }^{1}$, Dr Kalyan Kumar Ms (Ortho) ${ }^{1}$, Dr T Upendra ${ }^{2}$ \\ (iD, Dr Riyaz Sheik Ms (Ortho) ${ }^{3}$, Dr K Satya Kumar Ms (Ortho) ${ }^{*} 4$ 网 (iD) \\ ${ }^{1,2}$ Assistant Professor of Orthopaedics, Nri Academy of Sciences, Chinakakani, Andhra Pradesh, India \\ 2 Junior Resident of Orthopaedics, Nri Academy of Sciences, Chinakakani, Andhra Pradesh, India \\ 4 Professor \& Hod Orthopaedics, Nri Academy of Sciences, Chinakakani, Andhra Pradesh
}

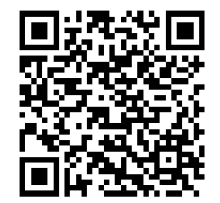

DOI: https://doi.org/10.29121/granthaalayah.v8.i11.2020.2440

Article Type: Research Article

Article Citation: Dr Harikrishna Koya Ms (Ortho), Dr Kalyan Kumar Ms (Ortho), Dr T Upendra, Dr Riyaz Sheik Ms (Ortho), and Dr K Satya Kumar Ms (Ortho). (2020). FUNCTIONAL OUTCOME OF COMMINUTED PROXIMAL TIBIAL FRACTURE TREATED BY LOCKING PLATE. International Journal of Research -GRANTHAALAYAH, 8(11), 227-236.

https://doi.org/10.29121/granthaa layah.v8.i11.2020.2440

Received Date: 10 November 2020

Accepted Date: 30 November 2020

Keywords:

Functional Outcome

Fracture

Locking Plate

\begin{abstract}
Most common intraarticular fractures in knee joint are tibial plateau fractures result from indirect coronal or axial compression forces. Tibial plateau fractures constitute $1 \%$ of all fractures in the human body and $8 \%$ fractures in the older people (1). Tibial plateau fractures include varied configuration of fracture pattern involving of medial condyle (10-23\%), lateral condyle (55-70\%), in both (11-30\%) with variable articular depression. Improper restoration of plateau fracture fragments leads to axis deviation and deformity and premature.
\end{abstract}

\section{INTRODUCTION}

Osteoarthritis2.Meniscus and ligamentous injuries may be associated with tibial plateau fractures (3).Schaztker classification for tibial plateau fractures widely used by an orthopedic surgeon for prediction of prognosis and planning management and initial injury assessment which divides fractures into six types. Each increasing numeric category specifies an increased level of energy imparted to the bone, thereby increasing the severity of fracture (3). Schatzker classification helps to direct orthopedic surgeons to adopt appropriate treatment modality (4).

Rigid conventional pate is thin and atrophic are more prone to secondary displacement due to inadequate buttressing and interruption of blood supply to bone due to soft tissue and periosteal stripping. Osteoporotic bone pose difficulty in poor fixation with conventional plate, so there evolved new concept of biological fixation plates PC-

(C) 2020 The Author(s). This is an open access article distributed under the terms of the Creative Commons Attribution License, which permits unrestricted use, distribution, and reproduction in any medium, provided the original author and source are credited. 
fix 1 later PC fix 2, more concepts cleared in innovation of this plates leads to development of less stabilizing system (LISS).

Hybrid of two combination plates has led to development of AO locking compression plates (LCP).(6)

This new technique offers numerous possibility's and good outcome fractures in complex and osteoporotic fractures. The treatment of these fractures aims to maintain the normal function of the knee joint and maintain alignment of fractures fragments and prevent deformity and secondary osteoarthritis in the knee joint and correlate the type of fracture and results with radiological findings.

\section{AIM AND OBJECTIVES}

1) To study the functional outcome of the fracture of proximal tibia.

2) To study the duration of union in proximal tibia fracture treated with LCP.

\section{REVIEW OF LITERATURE}

The fracture of the proximal tibia, which extends into the knee joint, can produce significant disability. At the University of Lowa, authors began treating tibial plateau fractures with early application of a cast brace. They encouraged early motion, weight-bearing to tolerance and unrestricted activities using crutches or other supports only when necessary lead to improved knee function (27).

Percutaneous fixation offers its best in isolated undisplaced fractures, split unicondylar fractures and in elderly osteoporotic bone. The advantages are decreased operative time, less blood loss, smaller incision, short hospital stay, and early rehabilitation (30).

An author reported two studies in the early 20 th century, having a satisfactory percentage of good to excellent short and long term results with the surgical method of treatment (29).

Bowes DN and Hohl M. studied of 159 cases of tibial plateau fracture of all types, treated by conservative (46\%) and surgery (54\%), evaluated by How and Luck method reported good excellent result in surgery (84\%) than conservative method (62\%) (30).

Roberts, in 1968, reported a hundred cases of tibial condyle fractures treated by conservative and surgical. The result was excellent in $72 \%$ conservative, $80 \%$ traction mobilization and $81 \%$ surgical. He advocates early mobilization preservation for menisci and repair of torn ligaments for best results. (31)

In 1979 Schatzker 32, reported 70 cases of tibial plateau fracture of all types treated by conservative (56\%) and surgical (44\%) with average follow up of 28 months. Acceptable results were obtained in 58\% of cases of the conservative group and $78 \%$ by open methods. Fracture treated by ORIF with buttress plate and bone grafting achieved $88 \%$ acceptable results.

A study of two hundred seventy-eight cases of tibial plateau fracture with an average follow up of 2.5 years, all treated by surgical methods. $89 \%$ acceptable result when surgery was done by inexperienced surgeons, $97 \%$ when done by experienced. They concluded the prognosis improve. (24) with the experience and with the accurate reconstruction of the articular surface. They also said post-traumatic osteoarthritis was directly proportional to the amount of displacement. (33)

Lauinger in 1986 did a 20 years follow-up of his earlier study extended in a series of 260 fractures of one of both condyles. $90 \%$ of the patients achieved excellent good results, and $10 \%$

achieved fair or unsatisfactory results. The inferior results were seen in an unstable split with depressed fractures.

There is another report26 out of treating 212 tibial plateau fractures of all types. They concluded that a medial unicondylar fracture with any displacement and all medially tilted bicondylar fracture should be operated upon. In fracture of lateral condyle ORIF is indicated when lateral tilt or valgus malalignment $>5 \mathrm{deg}$, articular step off $>3 \mathrm{~mm}$ or condylar widening $>3 \mathrm{~mm}$.

Sommer et al. published the results of the first general study of various locking compression plates in 2003. In their prospective study, they treated 144 patients with 169 fractures involving tibia (57), humerus (45), radius (19), and femur (18) and assessed the patients for one year. In 130 fractures, the healing took place in the expected period without any complications. A total of 27 complications occurred (19 patients), including implant loosening / pull out (5 patients).Plate failure ( 4 patients) non-union (1 patient), secondary fractures immediately adjacent to implant 
Dr Harikrishna Koya Ms (Ortho), Dr Kalyan Kumar Ms (Ortho), Dr T Upendra, Dr Riyaz Sheik Ms (Ortho), and Dr K Satya Kumar Ms (Ortho)

after a subsequent injury (5 patients) and infection(2patients). Analysis by the experts concluded that the mechanical complications arose entirely from technical errors of application. No purely implant-related complications occurred. They concluded that the LCP was technically proven. It's worth in complex fracture situations and revision operations after the failure of other implants (24).

\section{METHODOLOGY}

The study was carried out in NRI MEDICAL COLLEGE AND GENERAL HOSPITAL from 2017 to 2020. The total number of cases studied were 30 with the youngest $18 \mathrm{yrs}$ and oldest $65 \mathrm{yrs}$.

\section{Inclusion criteria}

All proximal tibial fractures involving both medial and lateral condyles aged from 18 years to 65 years both male and female.

\section{Exclusion criteria}

1) Patient aged below 18 years

2) Un displaced fracturs of proximal tibia.

3) Medically unfit patients for surgery.

On admission demographic data was recorded and thorough history and clinical examination was done. We assessed the soft tissue injuries even in the closed fractures followed by radiological assessment of the fracture with Schatzker classification.

As soon as the operation was planned, certain routine procedures like

1) Stabilize the patient hemodynamically and physical fitness for surgery was obtained.

2) Preoperative planning for selection of plate. Approach MIPO technique or open reduction and internal fixation.

3) In our series, all fractures are reduced with with $\mathrm{C}$-arm guidance.

4) To check for any associated fracture.

We chose open reduction and internal fixation with locking plate and MIPPO also in our series.The approach was either anteromedial or anterolateral incision for open reduction and internal fixation.The primary difference with the locking compression plate is the method of locking head screw insertion. Here since the locking head of the screw has to get locked in the locking part of the combihole. The direction of the drilling has to be perfect. Hence drilling for all locking head screws has to be after fixing the screw in drill sleeve.

\section{Postoperative}

In the immediate postoperative period. Care was given to the general condition, fluid balance, IV antibiotic and analgesics as per the protocol. This helped us to mobilize the patient faster.

\section{Mobilization}

Whenever stable internal fixation gained, the patient was mobilized after $48 \mathrm{hrs}$ after removal of the drains, for 2-3 days the range of motion allowed in stable fixation from the 5th day the range of motion was gradually allowed to increase to 90 degrees more after suture removal full range of movement was allowed. Plaster of Paris as given in the form of the external splint in unstable fixation and advice to do static quadriceps exercises in unstable fixation. Partial weight-bearing delayed until six weeks, and full weight-bearing allowed after 12-16 weeks depending on the union of fracture.

\section{Follow up}

The first follow up was usually between 4-6 weeks and later on patients were followed up at regular interval of 4-6 weeks till complete fracture union.During follow up: 
1) The course of fracture healing was documented radiologically with minimum 6 weeks interval. The moment of complete healing was defined as radiologically complete bone regeneration at fracture site.

2) Evaluation of any possible loss of reduction.

3) Assessment and analysis of any complication.

Follow up of out patients ranged from 16 weeks to 64 weeks.
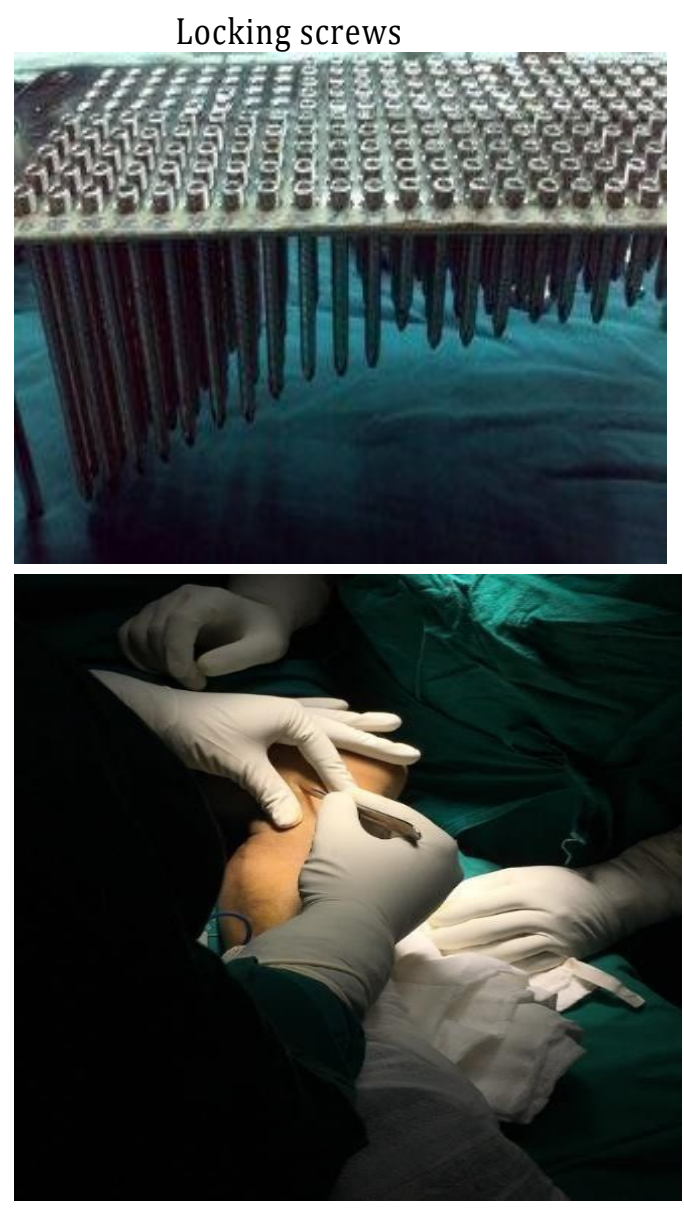

Locking screws and drill bit with driver

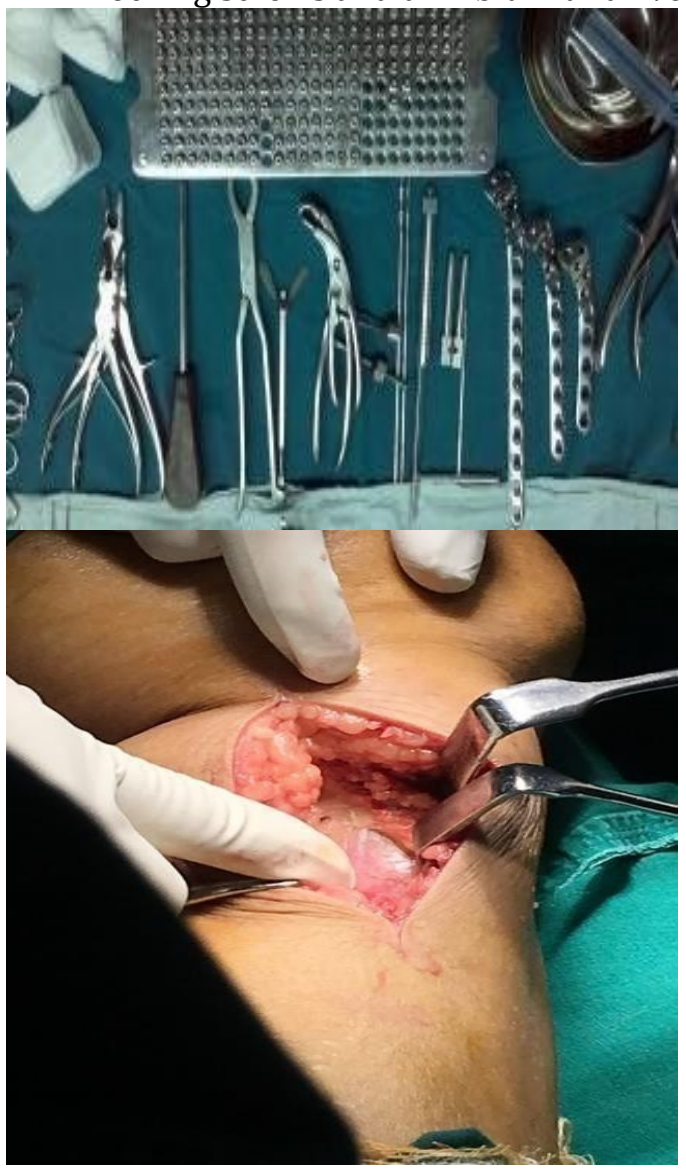

Open Reduction and Application Plate
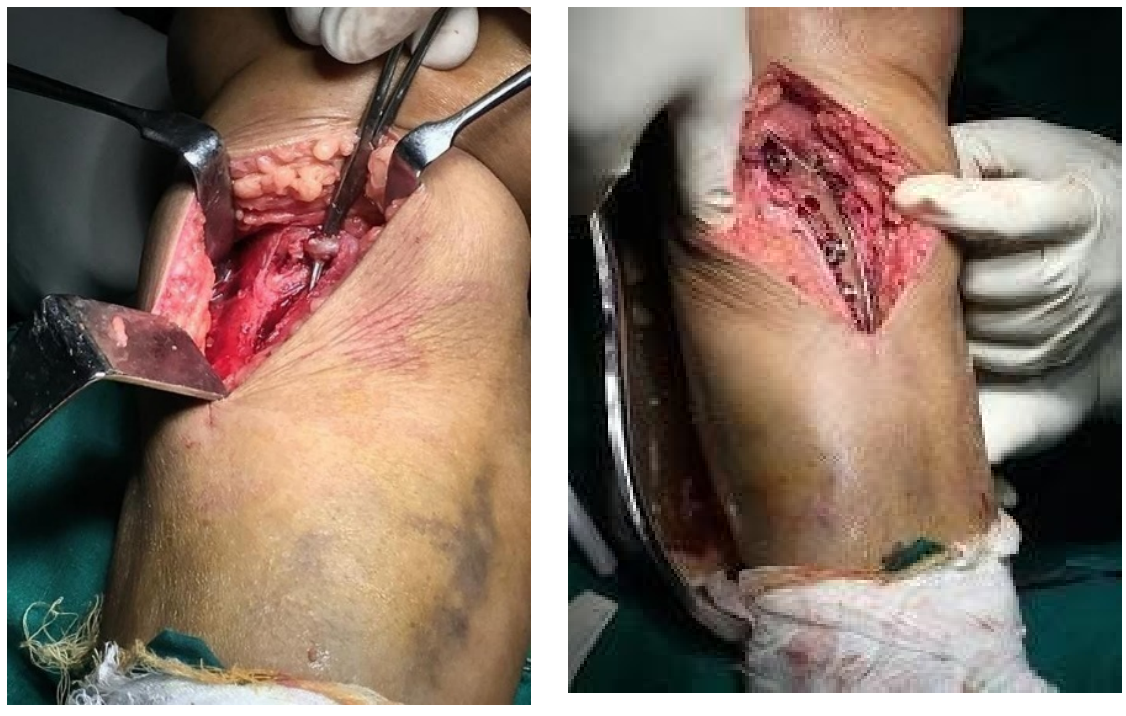
Dr Harikrishna Koya Ms (Ortho), Dr Kalyan Kumar Ms (Ortho), Dr T Upendra, Dr Riyaz Sheik Ms (Ortho), and Dr K Satya Kumar Ms (Ortho)

\section{RESULTS}

We studied 30 patients with 30 proximal tibial fracture who were treated with locking compression plate

Table 1: Age Distribution

\begin{tabular}{|c|c|c|}
\hline Age in Years & $\begin{array}{c}\text { Number } \\
\text { of Patients }\end{array}$ & $\%$ \\
\hline$<20$ & 1 & 3.3 \\
\hline $21-40$ & 19 & 63.3 \\
\hline$>40$ & 10 & 33.4 \\
\hline TOTAL & 30 & 100 \\
\hline
\end{tabular}

In our study the youngest patient was 20yrs old and the oldest was 65 years. Most of the patients belong to 2140 years of age group who are more prone for RTA.

Table 2: Gender Distribution

\begin{tabular}{|c|c|c|}
\hline Gender & Number of Patients & $\%$ \\
\hline Male & 25 & 83.4 \\
\hline Female & 5 & 16.6 \\
\hline Total & 30 & 100 \\
\hline
\end{tabular}

In our study most of the patient were male. It reflects that outdoor population were more prone for the proximal tibial fractures.

Table 3: Laterality of Fracture

\begin{tabular}{|c|c|c|}
\hline Side Involved & $\begin{array}{c}\text { Number of } \\
\text { Patients }\end{array}$ & $\%$ \\
\hline Right & 19 & 63.4 \\
\hline Left & 11 & 36.6 \\
\hline Total & 30 & 100 \\
\hline
\end{tabular}

Table 4: Mode of Injury

\begin{tabular}{|c|c|c|}
\hline Mode of Injury & $\begin{array}{c}\text { Number of } \\
\text { Patients }\end{array}$ & $\%$ \\
\hline Fall & 9 & 30 \\
\hline Rta & 21 & 70 \\
\hline Total & 30 & 100 \\
\hline
\end{tabular}

Table 5: Type of Fracture

\begin{tabular}{|c|c|c|}
\hline Type of Fracture & No. of Patients & Percentage \\
\hline I & 0 & 0 \\
\hline Ii & 4 & 13.33 \\
\hline Iii & 4 & 13.33 \\
\hline Iv & 8 & 26.66 \\
\hline V & 6 & 20 \\
\hline Vi & 8 & 26.66 \\
\hline
\end{tabular}

Table 6: Associated Injuries

\begin{tabular}{|c|c|c|}
\hline Assosciated Injuries & Number of Patients & Percentage \\
\hline Acl Injury & 2 & 6.66 \\
\hline
\end{tabular}


Functional Outcome of Comminuted Proximal Tibial Fracture Treated by Locking Plate

\begin{tabular}{|c|c|c|}
\hline Patella Fracture & 1 & 3.33 \\
\hline Both Bone Forearm Fracture & 2 & 6.66 \\
\hline Total & 5 & 16.66 \\
\hline
\end{tabular}

Table 7: Surgical Approach

\begin{tabular}{|c|c|c|}
\hline Side & Number of patients & $\%$ \\
\hline Anteromedial & 13 & 43.3 \\
\hline Anterolateral & 17 & 56.6 \\
\hline Total & 30 & 100 \\
\hline
\end{tabular}

Table 8: Union-Duration

\begin{tabular}{|c|c|c|}
\hline Duration -weeks & No: of patients & $\%$ \\
\hline$>16$ & 4 & 13.3 \\
\hline $12-16$ & 24 & 80.0 \\
\hline$<12$ & 2 & 6.7 \\
\hline
\end{tabular}

In our series most fracture union occurred between 12-16 weeks.

Table 9: Range of Motion

\begin{tabular}{|c|c|c|}
\hline Range of Motion & Number of Patients & $\%$ \\
\hline$>120$ & 20 & 66.7 \\
\hline $90-120$ & 7 & 23.3 \\
\hline$<90$ & 3 & 10.0 \\
\hline Total & 30 & 100 \\
\hline
\end{tabular}

In our series most patients had range of motion $>12$

Table 10: Clinical Results

\begin{tabular}{|c|c|c|}
\hline Clinical results & No.of cases & $\%$ \\
\hline Excellent & 21 & 70 \\
\hline Good & 7 & 23.3 \\
\hline Poor & 2 & 6.4 \\
\hline Total & 30 & 100 \\
\hline
\end{tabular}

In our series the clinical outcome of most of the patients was excellent. Which was done by MODIFIED HOHL AND LUCK EVALUATION method. 07 patients with good and 02 patients with poor.

Table 11: Complication

\begin{tabular}{|c|c|c|}
\hline Complication & Number of Patients & $\%$ \\
\hline Knee Stifness & 1 & 3.33 \\
\hline Knee Instability & 1 & 3.33 \\
\hline Varus Deformity & 1 & 3.33 \\
\hline Infection & 2 & 6.66 \\
\hline Total & 5 & \\
\hline
\end{tabular}

In our series we had 30 patients with 5 complication. one patient with knee stiffness due to associated patella fracture, one with knee instability due to associated ACL injury, one implant failure due to sever oseoporotic bone and infection, and one had infection post-op.

\section{Modified HOHL And Luck Evaluation Method}

\begin{tabular}{|c|c|c|c|c|c|}
\hline Grade & $\begin{array}{c}\text { Lack of } \\
\text { extension } \\
\text { (degrees) }\end{array}$ & $\begin{array}{c}\text { Range of } \\
\text { movement } \\
\text { (degrees) }\end{array}$ & $\begin{array}{c}\text { Valgus } \\
\text { orvarus } \\
\text { instability } \\
\text { (degrees) }\end{array}$ & $\begin{array}{c}\text { Walking } \\
\text { distance } \\
\text { (M) }\end{array}$ & Pain \\
\hline Excellent(all of the following) & 0 & $>120$ & $<5$ & $>3000$ & None \\
\hline
\end{tabular}


Dr Harikrishna Koya Ms (Ortho), Dr Kalyan Kumar Ms (Ortho), Dr T Upendra, Dr Riyaz Sheik Ms (Ortho), and Dr K Satya Kumar Ms (Ortho)

\begin{tabular}{|c|c|c|c|c|c|}
\hline $\begin{array}{c}\text { Good (Not more than one of } \\
\text { the } \\
\text { following) }\end{array}$ & $>0$ & $<90$ & $>5$ & $<1000$ & Mild on activity \\
\hline $\begin{array}{c}\text { Fair (not more than 2 of the } \\
\text { following) }\end{array}$ & $>5$ & $<75$ & $>5$ & $<1000$ & $\begin{array}{c}\text { Moderate on activity or } \\
\text { intermittent } \\
\text { at rest }\end{array}$ \\
\hline Poor & $\begin{array}{c}\text { All results } \\
\text { worse } \\
\text { than fair }\end{array}$ & & & \\
\hline
\end{tabular}
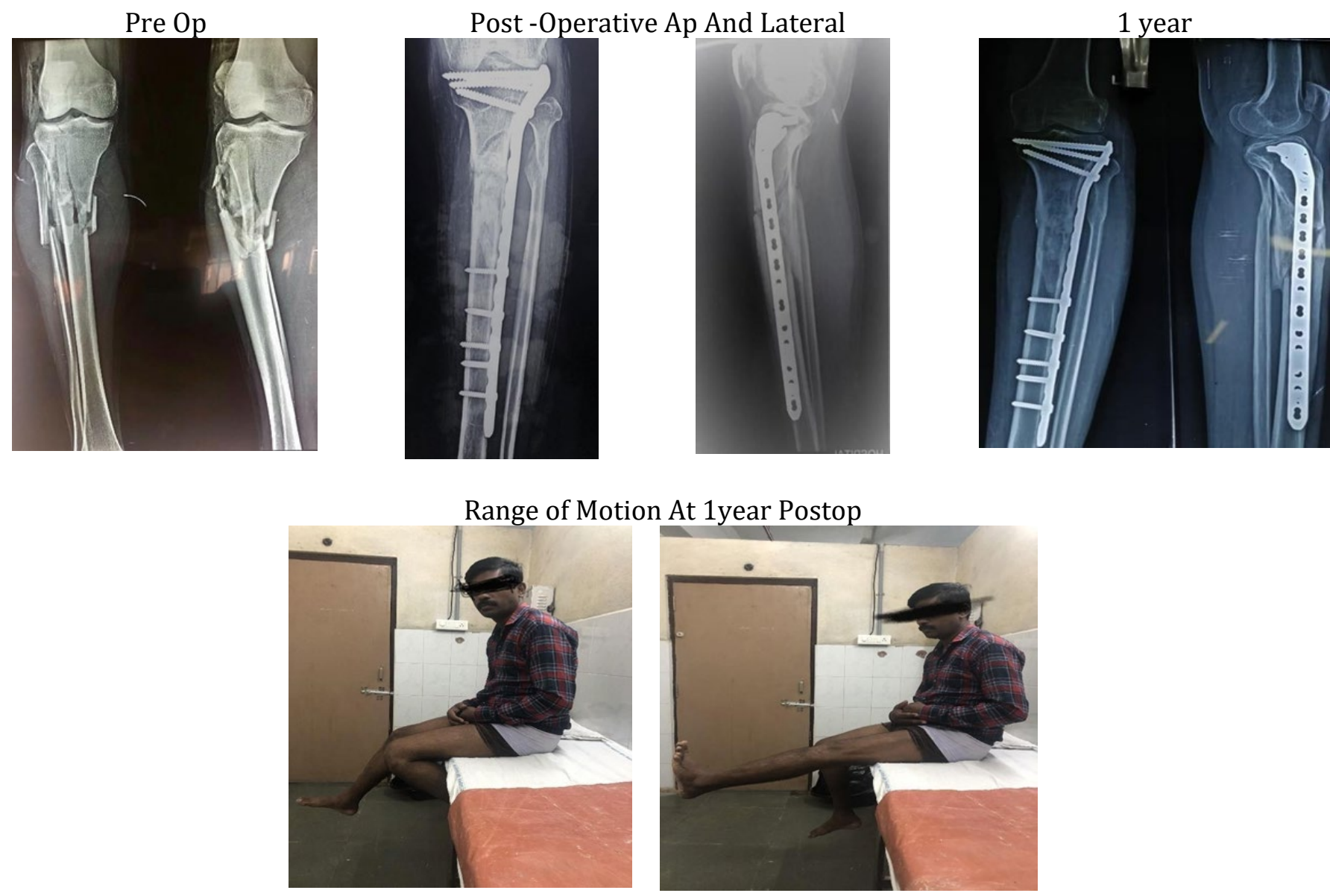

\section{Case 1}

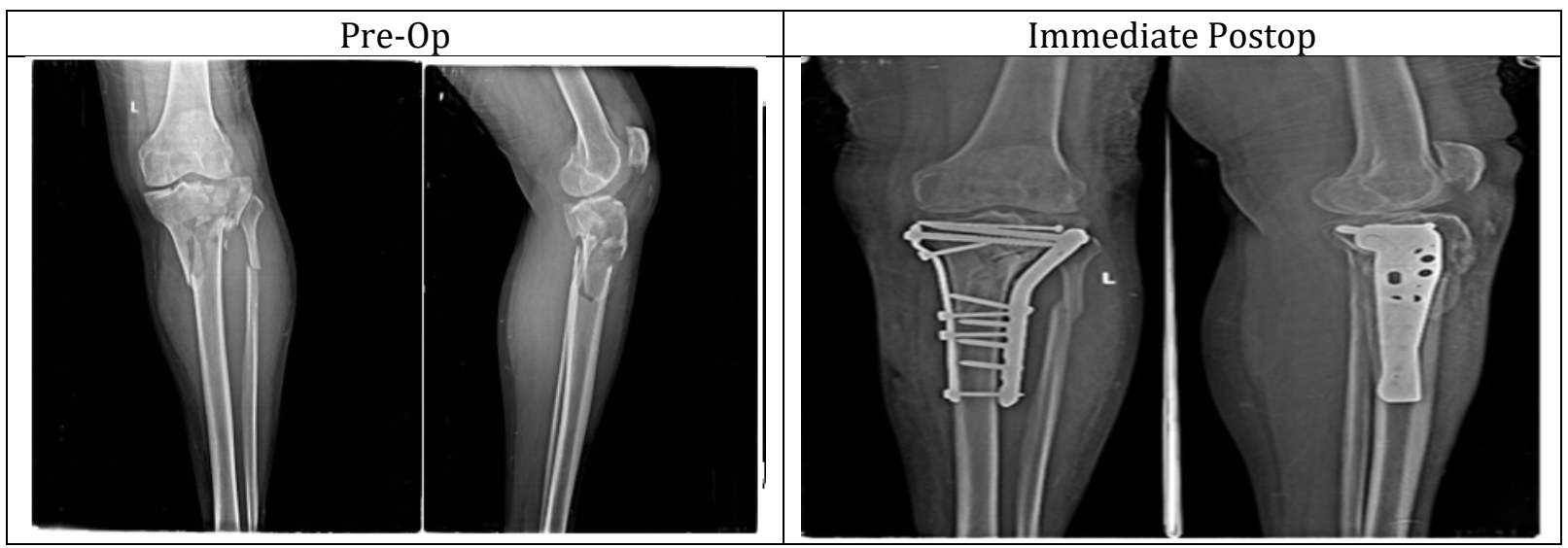




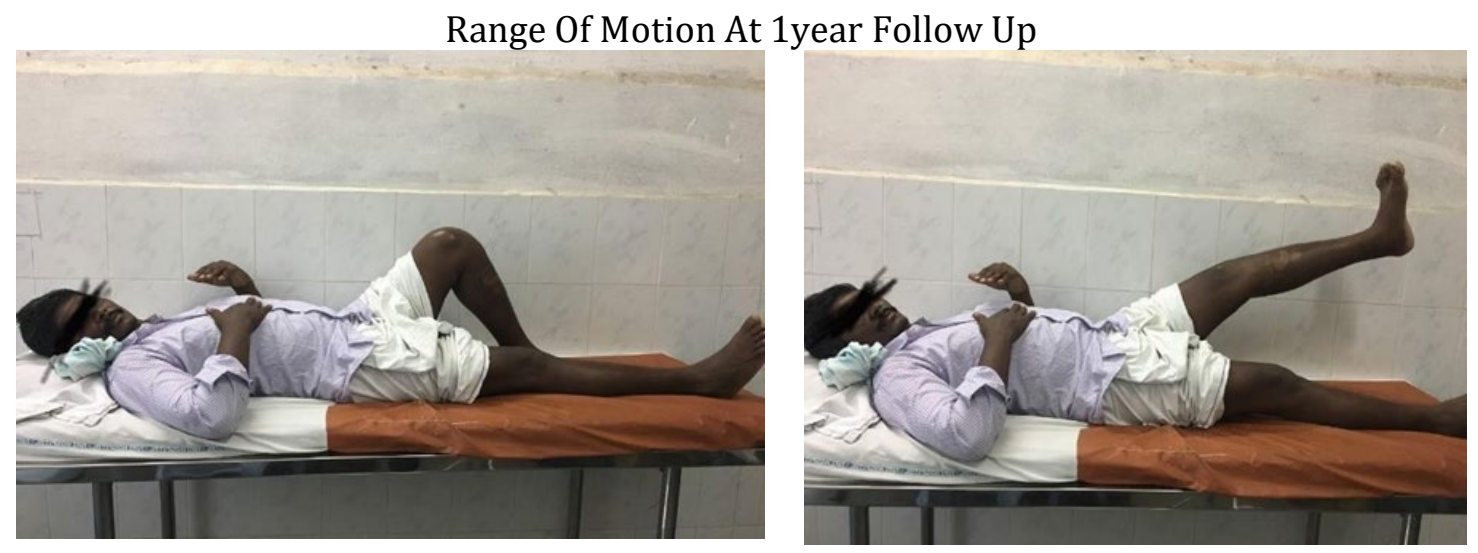

Case 2

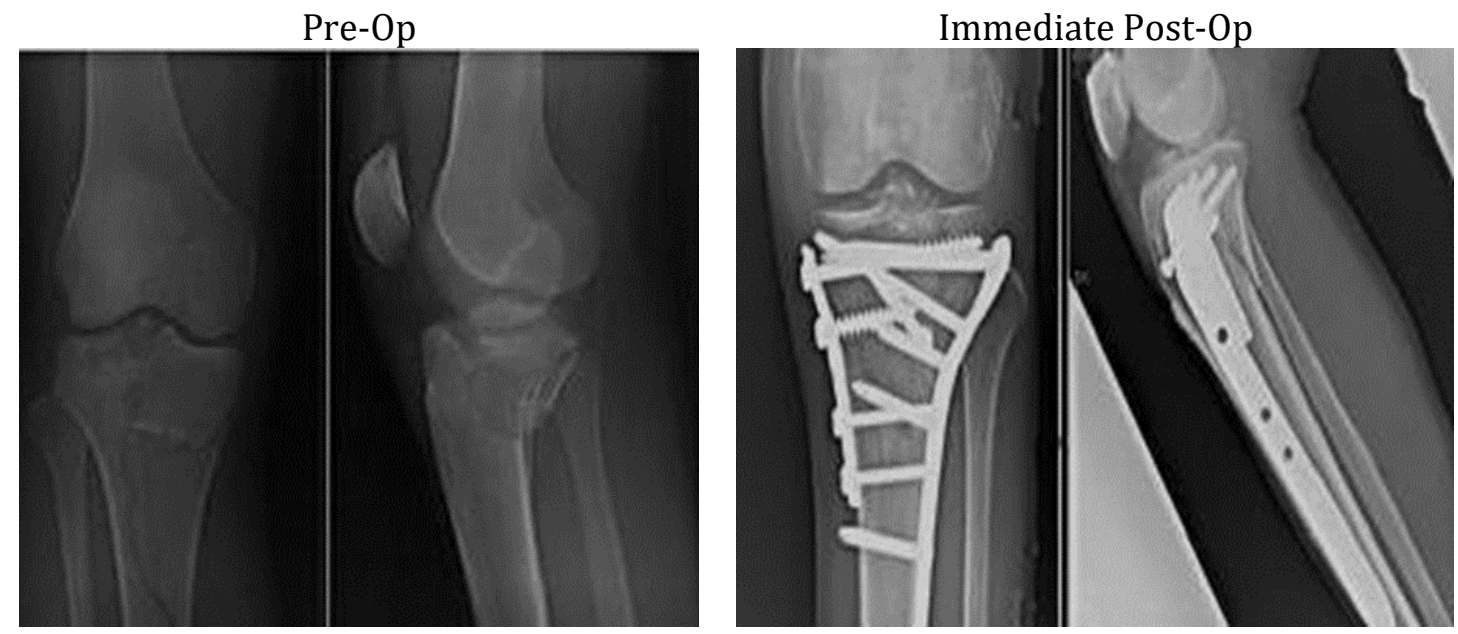

Range of Motion At 1 Year Follow Up

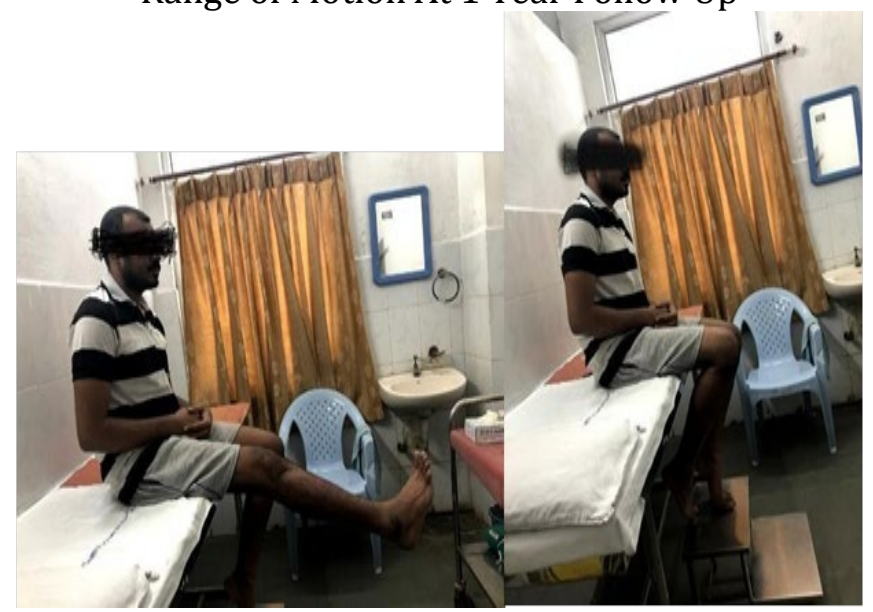

Case 3

\section{DISCUSSION}

Postoperative fractures primarily type V and type VI pose a challenge to orthopaedic surgeons for being very complex, as they are associated with a significant amount of comminution, severe soft tissue and ligament injuries, and associated other long bony injuries.

The treatment goals of high-energy bicondylar tibial plateau fractures include the satisfactory restoration of mechanical alignment, anatomic reduction, and stable fixation that allows an early range of motion of the knee(24). Besides, open reduction and internal fixation, mainly through the compromised soft tissue envelope, has been 
notably associated with major wound complications and more unplanned repeated surgical interventions and their severity (25).

In our study, analysis was done on the terms of the age of patients, sex distribution, laterality of fracture, mode of violence, analysis of the types, method of reduction and fixation, surgical approach and complications.

In our study, individuals between 20-49 years are the ones who have a maximum incidence of these high energy fractures. Ere Boume in 1981 has also presented with similar results, with $74 \%$ of the patients in the age group between 15-55 years, whereas 79\% of the patients present in the age group of 20-49 years. Our study also correlates well with the results of the study conducted by Seppo in 1993 on 130 patients where maximum patients belong to middle age group 30-49 years. Vasanand et al. (2013), studied 54, found $75 \%$ patient were in the age group 30-50 years.In our series majority of the patients are males $80 \%$, in Indian setup where the female population primarily work indoors and do not travel much this correlates with the study done by Siddhartha(43).Relation with occupation also follows the same as a more significant portion ( $93 \%$ )of the fractures among those associated with more outdoor activities as travelling to work, students, and drivers. While incidence was less common amongst those, who would engage less in such activities, e.g. farmers and homemakers (7 \% ). Besides vehicular motor accidents, these injuries were also found to result from a fall from height and less common with trivial fall.

In our study, the most common mode of injury is the road traffic accident $70 \%$ other being fall from height $30 \%$ In our study, we studied 30 cases of out of them most of the patients fall into Type IV, type V and type VI schatzker's classification. In our series, we approached with an anteromedial incision in 13 patients this approach has less stripping of soft tissue from bone contour plate to bone appropriately in 13 patient we prefer

anterolateral approach for lateral condylar displacement fracture and soft tissue injury on the medial side of the tibia.In our series, no cases of purely implant-related complications and the average time for union of fracture was 14 weeks.In our series, one patient developed knee stiffness due to patella fracture treated with conservatively and physiotherapy and regain 70 degree of flexion another patient present with knee joint instability. after fracture union ACL reconstruction done after six months and regained complete extension and more 90 degree flexion after physiotherapy.In our series one patient developed deep infection by10th postoperative day, he was treated with IV antibiotics ,implant removal and above knee pop cast application, subsequently infection was controlled and fracture union occurred at the end of 24 weeks postoperatively.In our series, one patient developed loss of reduction with the collapse of medial condyle at the end of 8 weeks of postoperative period treated with an above-knee plaster of Paris cast for 12 weeks, fracture united with minimal depression of medial condyle. Another patient developed varus deformity due to the collapse of medial condyle at 10 weeks of the postoperative period due to early weight-bearing he was treated with an application of above-knee pop cast for four weeks and advised to wear a knee brace while walking.In our series, one patient had associated anterior cruciate ligament injury he was treated with

above-knee pop cast till fracture union and advised to wear knee support while walking ACL repair in subsequent days depending on laxity of knee joint.

Benefits of early mobilization give better results in terms of good range of motion, less stiffness, and quick articular healing. In these cases, providing a significant amount of time for soft tissue healing may minimize the surgical wound-related problems as well as help in better compliance with the postoperative rehabilitation programme. Despite all these complications, we can achieve $70 \%$ excellent results and $23.33 \%$ good results (overall $85.7 \%$, acceptable results) with our standard surgical care. Besides, we had $6.4 \%$ of poor results in terms of functional outcome. These results are comparable and on par with other documented standard studies.

Rambold 1992 93\% acceptable

Seppo E 1993 85\% satisfactory

Joseph Schatzkar 1986 85\% satisfactory.

\section{CONCLUSION}

The conclusions can be drawn from the treatment of proximal tibial fracture with a locking compression plate in this study.A proximal tibial fracture is increasing with the increase in road traffic accidents. These fractures need optimum treatment, as most of them involved productive men. Preoperative soft tissue status and their repair at the right time significantly change the outcome. Fixation was advisable in osteoporotic bone because of its advantages of excellent anchorage to the bone by locking head screws .Even in osteoporotic bone, a bone graft is not essential for a defect in the metaphyseal region as LCP internal fixator system act as a single implant. It prevents the collapse

International Journal of Research -GRANTHAALAYAH 
of fracture intraoperatively and postoperatively subsequently bone deficient will heal by callus formation. When LCP used as a combined principle of fixation, we can reconstruct the tibial plateau with compression and prevent it from collapse by bridging principle. Thus we conclude that the locking compression plate system with its various type of fixation act as an excellent biological fixation, including in difficult fracture situations.

\section{SOURCES OF FUNDING}

This research received no specific grant from any funding agency in the public, commercial, or not-for-profit sectors.

\section{CONFLICT OF INTEREST}

The author have declared that no competing interests exist.

\section{ACKNOWLEDGMENT}

None.

\section{REFERENCES}

[1] Schulak DJ, Gunn DR. Fracture of the tibial plateaus. Clin Orthop 1975 June; 109:166-177.

[2] Koval KJ, Hulfut DL. Tibial plateau fracture: evaluation and treatment. J Am Acad Orthop Surg 1995;3(2):8694. Biyani A, Reddy NS, Chaudhary et al. The results of surgicalmanagement of displaced tibial plateau fracture in the elderly. Injury 1995;26(5):291- 297.

[3] Wagner M. General principles for the clinical use of the LCP. Injury 2003 Nov;34, Suppl 2: B31-42.

[4] Sommer C, Gautier E, Muller M. For clinical application of the LCP. Injury 2003 Nov; 34, Suppl 2:B43-54.

[5] Stoffel K, Dietaru. Biomechanical testing of the LCP how can stability in locked internal fixator be controlled. Injury 2003 Nov;34, Suppl2:B11-9.

[6] Sobotta. Atlas of human anatomy. Putz R, Pabst R edts. 21st edn, vol. 2 Philadelphia, Lippincott Williams and Wilkins; 2000. p. 263-347.

[7] Netter FH. Anatomy. In : Teterboro new Jersey Icon learning system. 3rd edn. 2003. p. 488-94.

[8] Whittle AP, Wood II GW. Fracture of lower extremity. Chapter 51. In: Campbell operative orthopedics. Canale ST ed. 10th edn, Vol. 3. New York, Mosby; 2003. p.

[9] Waddell JP. Fracture of the tibia and fibula. Court Brown C, Penning D, edts.Oxford, Butterworth; 2000. p. 3854.

[10] Tillman M. Moore Fracture plateau fractures: An analysis of the results of treatment in 60 patient.clin Orthop 1984;182:193.

[11] Muller ME et al. The comprehensive classification of fracture of long bones. New York, springer 1990.

[12] Watson JT. High energy fractures of the tibial plateau.Orthop clin N Am 1994;25:728-752.

[13] Weiner LS,Kelly M,Yang E et al. the use of combination internal fixation and hybrid external fixation in sever proximal tibial fractures. J orthop trauma 1995;9:244- 250.

[14] Netter FH. Anatomy. In: Teterboro new Jersey Icon learning system. 3rd edn. 2003. p. 488-94. 